\title{
Reflection of the Accession Process of Turkey to European Union on Doctoral Theses Written About Foreign Language Education in Turkey 1987-20171
}

\author{
DOI: $10.26466 /$ opus.826337 \\ *
}

\section{Cağlar Demir*}

* Öğr. Gör. Dr., Yabancı Diller Yüksekokulu, Balıkesir Üniversitesi, Balıkesir/Türkiye

E-Mail: erkandemir508@hotmail.com

ORCID: 0000-0002-3447-9596

\begin{abstract}
The European Union is the most important political and social integration of the 20th century. EU member countries have worked to develop common policies not only in the field of economy, but also in social, cultural, political and educational fields. In the European Union member countries, foreign language teaching is one of the most important topics in the field of education. European Union accepted Turkey as a candidate country in the enlargement process. With Turkey's full EU membership process which started in 2005, importance of foreign language education increased in all educational institutions in Turkey. Ministry of National Education and Universities have carried out and implemented studies on pre-school language education, curriculum, language teaching methods, and foreign language teacher education within the scope of language education. Undoubtedly, academic studies on foreign language teaching play an active role for a successful language education. In this study, how Turkey's EU membership process is reflected in the doctoral theses on foreign language education published in 1987-2017 and how the research topics in doctoral theses changed with the start of the membership process were investigated. Document analysis technique was used in the research. Since the universe was used as a sample in the study, it is a study of complete inventory. 58 doctoral theses were examined. They were analyzed in terms of titles. Practical and concrete proposals related to foreign language teaching in Turkey were presented in accordance with the results obtained in the light of findings of the research. The study shows that with the effect of the Turkey's accession process to European Union full membership, research topics in doctoral dissertations have changed and focal points in PhD theses were determined as foreign language teaching, Creative writing skills, Creative thinking skills, Understanding By Design, Mobile Multimedia Support,Web based Foreign Language Teaching,Detailing Theory, Intercultural Communication.
\end{abstract}

Keywords: $\quad$ Turkey, European Union, Foreign Language Education, Doctoral theses.

\footnotetext{
${ }^{1}$ This study is based on my doctoral thesis 'Holistic Analysis of Postgraduate Theses on Foreign Language Teaching in Turkey with Actor Technic Perspective.'
} 


\section{Türkiye'nin Avrupa Birliği'ne Geçiş Sürecinin Türkiye'de Yabancı Dil Öğretimi Üzerine Yazılan Doktora Tezlerine Yansıması 1987-2017}

Öz

Avrupa Birliği, 20.yüzyılın en önemli siyasi ve sosyal entegrasyonudur. AB üyesi ülkeler, sadece ekonomi alanında değil, sosyal, kültürel ve siyasal ve eğitim alanlarında ortak politikalar geliştirmek için çalışmalar yürütmüşlerdir. Avrupa Birliği üyesi ülkelerde, yabancı dil öğretimi, eğitim alanındaki en önemli başlıklardan biridir. Avrupa Birliği genişleme sürecine Türkiye'yi de aday ülke olarak kabul etmiştir.2005 yılında başlayan AB tam üyelik süreci ile beraber Türkiye'deki tüm eğitim kurumlarında yabancı dil eğitimine önem artmıştır. Milli Ĕ̆gitim Bakanlığı ve Yüksek Öğretim Kurumuna bağhı Üniversiteler, dil eğitimi kapsamında, okul öncesi dil eğitimi, müfredat, dil öğretim metodlar, yabancı dil öğretmeni eğitimi başlıklarında çalışmalar yapmış ve hayata geçirmişlerdir. Yabancı dil öğretimi konusunda yapılan akademik çalışmalar, hiç şüphesiz, başarılı bir dil eğitimi için etkin rol oynamaktadır. Bu çalışmada, Türkiye'nin AB üyelik sürecinin Türkiye'de yabancı dil eğitimi üzerine 1987-2017 arası yapılan doktora tezlerine nasıl yansıdı̆̆ı, tezlerdeki konuların üyelik sürecinin başlanması ile nasıl değişiklik gösterdiğgi araştırılmıştır. Araştırma'da doküman analizi tekniği kullanılmıştır. Çalışmada evren, örneklem olarak kullanıldığından, araştırma bir tam sayım çalışmasıdır. 58 doktora tezi incelenmiştir. Tezler, araştırma konuları açısından incelenmiştir. Analizler doğrultusunda sonuçlar tartışılıp elde edilen bulguların ışı̆̆ında Türkiye'deki yabancı dil öğretimi ile ilgili araştırma ve uygulamaya dönük somut öneriler sunulmuştur. Bu çalışma, Avrupa Birliği tam üyelik sürecinde yabancı dil öğretimi ile ilgili doktora tezlerinde araştırma alanları değiş̧miş ve odaklanılan konuların, yaratıcı düşünme ve yazma becerileri, Anlama temelli Tasarım, Taşınabilir Multi-media desteği, Web tabanlı Yabancı Dil Öğretimi, Ayrıntılama Teorisi, kültürlerarası iletişim olduğunu tespit edilmiştir.

Anahtar Kelimeler: Türkiye, Avrupa Birliği, Yabancı Dil Eğitimi, Doktora Tezleri. 


\section{Introduction}

The 20th century witnessed great changes in the social, economic and political lives of countries with the impact of dazzling developments in science and technology. In the balance of power in the world, European countries started economic cooperation after the second world war and established the European Coal and Steel Community. Founded by West Germany, France, Belgium, the Netherlands, Italy and Luxembourg, this community has today transformed into the European Union, a multinational community that includes social, cultural and political dimensions as well as its economic dimension (Sağlam, 2017).

European Union that the way to become a stronger union was through enlargement and accepted 'Czech Republic, Hungary, Poland, Slovakia, Slovenia, Lithuania, Latvia, Estonia, Malta and GCASC' (Çakmak, 2006, p.84) to full membership. Turkey wanted the modernization process inherited from the Ottoman Empire to be crowned with EU membership and political, social, military and took concrete steps in the field of law, policy, military, social life and education. EU desired to see Turkey in this organization with its young population, important geographical position and dynamic economy. EU - Turkey relations which started in 1963 reached a critical stage in 2004. In December 17, 2004 the European Council, at the final declaration of the summit in Brussels, declared that Turkey fulfilled the Copenhagen political criteria to start full membership negotiations (Sayin, 2016, p.48).

One of the issues that the European Union particularly dwells upon is education. The opportunities offered by the EU in the field of education are international education, vocational education, exchange programs, innovative education and training programs, the use of new technologies in education and the mutual recognition of diplomas, a network of academicians and a consultation platform for professional expertise, comparison and policy making (Cansever, 2009). In addition to ensuring economic, social and political integration, the European Union has provided economic support to member countries to implement Comenius School Projects among European Union countries in order to establish common educational goals, to consolidate peace by establishing European Citizenship, and to ensure employment within the Union in the long term (Kulaksiz, 2010 
P.8) As all other European Union member states, Turkey, to solve the problems of the education system and better quality of discourse globally to establish an educational system and policies, has restructured the education system at all levels with the human and financial support of various supranational organizations like EU, OECD and World Bank, actors of globalization since 2003. First of all, the teaching programs / curriculums were renewed on the axis of constructivism, student-centered education and multiple intelligences (Çelik, 2012). Besides, the competencies and skills aimed to be acquired by students with the curriculum are as follows: communication in mother tongue, communication in foreign languages, mathematics competence, science and technology competence, digital competence, learning to learn, taking initiative and entrepreneurship perception, social and public competencies, cultural awareness (MEB, 2017, p.8).

With the effect of European Union accession process and globalization, Turkey conceived that its social development and progress lie in scientific studies and strong communication with outher world and took concrete steps in higher and secondary, primary education to provide effective foreign language education. It made arrangements in language teaching methods, foreign language teacher training, foreign language course hours and teaching materials. In Turkey's EU accession process, foreign language education program was revised in 2005 and changes have been made in terms of aims, content, teaching-learning process and evaluation. The changes in this program have been influenced by the constructivist philosophy. In this context, subject-based language learning such as mathematics, geography and music, cooperative learning and drama practices, and performance-based assessment programs were encouraged to make foreign language education more effective (Sağlam, 2011).

Various academic studies on language teaching in Turkey have been done in language departments of Turkish universities in order to contribute to language education in Turkey and literatüre. In particular, with the effect of EU vision, language studies have been given great significance. This study explores what areas doctoral theses on foreign language teaching center upon, what research topics have been given emphasis after 2004, when EU-Turkey full membership process started, what topics can be worked on for further academic studies. 


\section{Literature Review}

This section involves recent reviews about Turkey-EU relations and the effects of Turkey-EU relations on Turkish education system.

\section{Turkey's Accession Process to European Union Membership and its Ef- fects on Turkey's Education System}

European Union was founded in 1993 to integrate European countries to protect, sustain and empower EU member countries' economy in the competitive global economy. Schuller (2009) states that The Lisbon Agenda (2000) established for the European Union the goal to become the most competitive economy in the world in 2010. European people were also concerned about security and defense. So it is also called a political union. The goals and values of the EU can be stated as;

- promote peace, its values and the well-being of its citizens

- offer freedom, security and justice without internal borders

- sustainable development based on balanced economic growth and price stability, a highly competitive market economy with full employment and social progress, and environmental protection

- combat social exclusion and discrimination

- promote scientific and technological progress

- enhance economic, social and territorial cohesion and solidarity among EU countries

- respect its rich cultural and linguistic diversity

- establish an economic and monetary union whose currency is the Euro (The EU in Brief, 2019).

One of the countries aiming at joining the EU membership is Turkey for its goal, as other EU member countries, is to develop social, economic and cultural lives of the citizens by making improvements in all its organizations and law. The best way for Turkey to make structural and management reforms was to take EU as a model. So, Turkey started negotiations for full membership with EU in 2005.

When Turkey's accession process to EU is analysed, it goes without saying that Turkey has shown a significant performance in adopting EU 
membership principles. EU Brussels Summit held on 17-18 June 2004, including comprehensive constitutional amendment held in May, Turkey's reform process, which welcomed the progress made so far and the Turkish government has received the support of their efforts in this direction (Özer, 2009, p.97). Within the context of EU membership, Turkey fullfilled the commitment about the 26th chapter related to education and culture. With this chapter, EU 'envisages to promote cooperation within the framework of common policies such as, increasing the quality of education, educational attainment, employability, cultural dialogue, preserving the cultural richness, common cultural heritage and to strenghten and support cooperation avtivities between member states' (Chapter-26-Education and Culture, 2020).

European Union aims to have a well educated European youth and community. That is why, this organization produced new policies about education. European Union pinpoints ' the quality and efficiency of lifelong learning and mobility, equity and citizenship, innovation and creativity' (Miller, 2017, p.23). As an important EU candidate country, Turkey also took decisive actions to provide good education with its young population in accordiance with EU education goals. In that respect, Ministry of National Education and Higher Education 'aims to cooperate in multinational education, training and youth activities, foreign education and exchange opportunities, innovative education and training project opportunities, creating academic and vocational expertise networks, implementing a common vocational education policy and spreading vocational education 'within the framework of relations with the EU' (Kulaksiz, 2010 p.76). In particular, foreign language teaching was of crucial importance for The Council of Europe for 'English has an undisputed economic usefulness in the European labour market' (Gazzola, 2016, p.7). European Union dwells on the significance of English language in intercultural communication for 'the teaching of English, and of all linguistic varieties in the same position, should be dealt with specifically, in particular with respect to its functions in plurilingual education and intercultural communication' (Language Policy Division, 2007, p.30). EU also urges member countries to provide foreign language education for preschool 
children. It is stated in Common European Framework of Reference for Languages: Learning, teaching, assessment;

'The Council of Europe recognised the importance of the life-long provision for language learning for all at an early stage. In a series of projects over many years it has provided a forum for all those involved in policy making to come together with teachers, teacher trainers and support services to formulate policies and translate them into concrete objectives and practical ways of achieving them. The Council helps member states to implement reforms and encourages innovation in language teaching and teacher training. In general, it facilitates the pooling of international experience and expertise, and promotes a coherent, learner-centred methodology which integrates aims, content, teaching, learning and assessment in a harmonious approach based on common principles. The Council of Europe attaches considerable importance to promoting linguistic diversity in Europe and has assisted member states in producing planning instruments to promote the teaching of almost thirty national and regional languages' (Bailly, S and Devitt, S and Gremmo, MJ ed.2001, p.7).

Turkish education policy, curriculum design and foreign language education have undergone remarkable changes for the last two decades. Second language teaching in Turkey started to be taught at fourth grade in 1998 and lowered to second class at primary school in the 2013-2014 academic year. The weekly course schedule of the primary education institutions (elementary and junior high schools) was changed with the decision of the Board of Education of Ministry of Education, dated 25 June 2012 and numbered 69 . The weekly course schedules of primary education institutions (primary and secondary) started to be applied gradually starting from the fifth grade (Demir, 2020). With the acceptance of the lifelong Learning Strategy, Bologna Process, National Youth and Sports Policy Paper, UNESCO Convention on Protection and Promotion of the Diversity of Cultural Expressions, Bologna Process, Multilingualism and Cultural Right, Institute of Living Languages, Turkey has transformed its education system in the positive way. Turkish students, teachers and academics have had the chance to join Erasmus programmes. In that way, they broaden their horizon in different European countries by interacting with the teaching staff and students from different parts of the world. 


\section{EU Membership and Turkish Higher Education}

Global economy demands innovation, knowledge, know-how, well-informed students from universities in the world. European Union has made considerable investment in education from pre-schooling to university and doctoral levels to secure its position in the competitive global economy and implemented Bologna process which 'has expanded into a number of areas to promote the European Higher Education Area. It is also now linked to the "Lisbon Strategy" or "Lisbon Agenda", which was signed in 2000 by the heads of governments of the European Union during the Portuguese presidency, and which aims to promote growth and employment in Europe in order to transform the European Union into the most competitive economy in the world by 2010 '(Turkish Industrialists' and Businessmen's Association, 2008). Higher education is crucial for European Union for production of knowledge brings prosperity. Mazza (2008, p.49) stresses that having traditionally been at the core of knowledge production within nation states, they are expected to play a role tomorrow in the ambitious move towards a European knowledge economy. Bologna process is so significant for the improvements of higher education in all European countries and EU member countries in terms of producing knowledge and students and academics' interaction with EU students and academics as Navracsics (European Commission/EACEA/Eurydice,2015) states;

'Education has a pivotal role to play in helping them find their place in the labour market and society as a whole, and the Bologna Process must contribute to that. Its continued development, especially of its social dimension, is essential to the future prosperity, wellbeing and sustainability of our higher education systems and societies. The Bologna Process has created a space for dialogue and cooperation which reaches far beyond Europe' (Turkish Industrialists' and Businessmen's Association, 2008).

Turkish National Education and Council of Higher Education determined their education strategy in EU Bologna process and took concrete steps to meet the expectations of Turkish state, the young generation and companies. For the last decade, when the financing of higher education in Turkey is analysed, it is noteworthy that Turkey has made great effort to 
support tertiary education as it is emphasized in Bologna Process implementation report:'Countries that have different levels of GDP per capita and annual expenditure per student make a similar relative financial effort towards tertiary education. For instance, Turkey spends slightly more than $50 \%$ of its GDP per capita on each tertiary student which is nearly as much as Denmark and slightly more than Sweden while its GDP per capita and annual expenditure per student are less than half of the one in these two countries in 2011' (European Commission/EACEA/Eurydice. 2015, p.44).

Turkey's accession process to EU membership also affected language course contents and academic research areas in foreign language education at master's and doctoral levels. This study examines how research topics in doctoral theses have changed by years, in particular, from 2005 to 2017 and what topics are placed more emphasis in these theses.

\section{Methodology of the Research}

Document analysis technique was used with the support of quality research technique. Document analysis is a qualitative research method used to diligently and systematically analyze the content of written documents (Wach, 2013, as cited in Kiral, p.4 2020). Document analysis is a systematic method used to examine and evaluate all documents, both printed and electronic materials. Like other methods used in qualitative research, document analysis requires the analysis and interpretation of data in order to make sense, create an understanding about the relevant topic, and develop empirical knowledge (Corbin and Strauss, 2008, as cited in Kıral, 2020). YOK (Higher Education Council of Turkey) Thesis Database was be used for data collection. Population is comprised of 58 doctoral thesis on foreign language teaching published between 1987-2017. As the thesis study started as of the end of 2017, it is aimed to determine the changes in the historical process of doctoral theses subjects and academic studies in the field of foreign language education by considering a 30-year period from the most recent data back to 1987. Research is a study of complete inventory for population sample in this study. Sample properties are shown in Table 1. Research is a study of complete inventory for population sample in this study. Sample properties are shown in Table 1. 
Table 1. Sample Properties

\begin{tabular}{|c|c|}
\hline Years & PhD Thesis \\
\hline 2017 & 2 \\
\hline 2016 & 3 \\
\hline 2015 & 3 \\
\hline 2014 & 2 \\
\hline 2013 & 5 \\
\hline 2012 & 3 \\
\hline 2011 & 4 \\
\hline 2010 & 4 \\
\hline 2009 & 3 \\
\hline 2008 & 3 \\
\hline 2007 & 1 \\
\hline 2006 & 1 \\
\hline 2005 & 0 \\
\hline 2004 & 3 \\
\hline 2003 & 5 \\
\hline 2002 & 3 \\
\hline 2001 & 3 \\
\hline 2000 & 0 \\
\hline 1999 & 5 \\
\hline 1998 & 1 \\
\hline 1997 & 0 \\
\hline 1996 & 1 \\
\hline 1995 & 1 \\
\hline 1994 & 0 \\
\hline 1993 & 1 \\
\hline 1992 & 0 \\
\hline 1991 & 0 \\
\hline 1990 & 0 \\
\hline 1989 & 0 \\
\hline 1988 & 1 \\
\hline 1987 & 0 \\
\hline Total & 58 \\
\hline
\end{tabular}

As shown in Table 1, 58 doctoral theses on language teaching were conducted between 1987 and 2017. According to the table, it is seen that the number of doctoral theses on language teaching increased significantly between 2004 and 2017. This situation can be associated with the increase in importance to higher education and doctoral studies with the start of the EU process. 


\section{Findings Related to the Titles of Doctoral Theses}

\section{The findings related to the titles of $\mathrm{PhD}$ theses on foreign language teaching in Turkey between 1987-2017 are shown in Table 2.}

Table 2.Titles of PhD Theses on Foreign Language Education by Years.

\begin{tabular}{|c|c|}
\hline Year & Title \\
\hline 1988 & Programmatic Teaching in Second Language Teaching \\
\hline 1993 & $\begin{array}{l}\text { Comparison of the Principles and Techniques applied in Foreign Language Teach- } \\
\text { ing in Private Secondary Education Institutions in terms of some Variables }\end{array}$ \\
\hline 1995 & New Trends in Second Language Teaching and Teaching French in Turkey \\
\hline 1996 & $\begin{array}{l}\text { Communicative Approach to Foreign Language Teaching and Effect of Grammar- } \\
\text { Translation Method on Student Achievement }\end{array}$ \\
\hline 1998 & $\begin{array}{l}\text { Literature Teaching with Deconstruction and Semiotics Approaches in the Classes } \\
\text { of Foreign Language Education: Short Stories and Two Novels of D. H. Lawrence }\end{array}$ \\
\hline 1999 & $\begin{array}{l}\text { Teaching EFL Through English or Content: Implications for Second Language } \\
\text { Learning }\end{array}$ \\
\hline 1999 & $\begin{array}{l}\text { Comparison of the Effect of Modular Teaching Method and Second Language } \\
\text { Teaching on the Success of Students in Second Language Teaching (F.Ü. Technical } \\
\text { Education Faculty) }\end{array}$ \\
\hline 1999 & Acquisition of Reading Comprehension Skills in Second Language Teaching \\
\hline 1999 & $\begin{array}{l}\text { The Problem of Educational Policy in Second Language Teaching and a New Ap- } \\
\text { proach }\end{array}$ \\
\hline 1999 & Causes of Anxiety in Speaking and Writing Lessons in Second Language Learning \\
\hline 2001 & Research on the Effect of Anxiety on Foreign Language Teaching \\
\hline 2001 & $\begin{array}{l}\text { An Evaluation of Foreign Language Teaching in terms of some Variables at an } \\
\text { Early Age }\end{array}$ \\
\hline 2001 & $\begin{array}{l}\text { The Relationship between Collaboration and Professional Development: Possible } \\
\text { Effects of EFL Student Teacher/Supervising Teacher Dialogue on the Belief and In- } \\
\text { structional Practices of the EFL Supervising Teachers }\end{array}$ \\
\hline 2002 & $\begin{array}{l}\text { Textbook Proposal for Teachers and Students for the Lesson, 'Approaches in Sec- } \\
\text { ond Language Teaching in English Language Teaching Departments of Education } \\
\text { Faculties.' }\end{array}$ \\
\hline 2002 & Short Story Analysis with Structuralist Method in Foreign Language Teaching \\
\hline 2002 & $\begin{array}{l}\text { Learning Strategies and Foreign Language Teaching at an Early Age in Turkish } \\
\text { Education: The Case of Galatasaray }\end{array}$ \\
\hline 2003 & Foreign Language Teaching and Reflections after Structuralism \\
\hline 2003 & $\begin{array}{l}\text { (in German) Computer Usage Areas and Possibilities in Second Language Teach- } \\
\text { ing }\end{array}$ \\
\hline 2003 & The Place and Importance of Drama in Foreign Language Teaching \\
\hline 2003 & Case Study about an Autistic Child Learning a Foreign Language \\
\hline 2003 & Action-Oriented Approach to Children in Foreign Language Teaching \\
\hline 2004 & Relationship between Personality and Language Learning and Teaching \\
\hline 2004 & $\begin{array}{l}\text { The Linguistic Examination of Idioms in Modern Arabic and its Place in Foreign } \\
\text { Language Teaching }\end{array}$ \\
\hline
\end{tabular}


Table 2. Titles of PhD Theses on Foreign Language Education by Years.

\begin{tabular}{|c|c|}
\hline Year & Title \\
\hline 2004 & $\begin{array}{l}\text { Learning Styles of Student-Teacher in English Language Teaching Departments in } \\
\text { Some Faculties of Education with respect to Foreign Language Learning and } \\
\text { Teaching }\end{array}$ \\
\hline 2006 & $\begin{array}{l}\text { The Effects of "Clustering" Written Expression Technique on Student Attitude and } \\
\text { Success in Achieving Second Language Teaching }\end{array}$ \\
\hline 2007 & $\begin{array}{l}\text { Implications of Second Language Learning in terms of Turkey's Cultural Integra- } \\
\text { tion into the EU: A Survey Study on EFL Learners in Turkey }\end{array}$ \\
\hline 2008 & $\begin{array}{l}\text { Application of Alternative Methods in Foreign Language Teaching with German } \\
\text { Literary Texts }\end{array}$ \\
\hline 2008 & $\begin{array}{l}\text { Foreign Language Learning at early ages: A Study on Factors Affecting Foreign } \\
\text { Language Learning of Preschool Children }\end{array}$ \\
\hline 2008 & $\begin{array}{l}\text { French Text and Discourse Analysis in Foreign Language Teaching: Reading } \\
\text { Methods for Non-Literary Texts }\end{array}$ \\
\hline 2009 & $\begin{array}{l}\text { The Effect of European Union Accession Process, the EU General Education Policy } \\
\text { and EU Foreign Language Policies on Second Language Education and Policies in } \\
\text { Turkey }\end{array}$ \\
\hline 2009 & $\begin{array}{l}\text { The Effects of Creative Writing on Success and Writing in Foreign Language } \\
\text { Teaching }\end{array}$ \\
\hline 2009 & $\begin{array}{l}\text { According to Detailing Theory, the Effect of Materials on Students' Academic } \\
\text { Achievement and Retention of Learning in Foreign Language Learning }\end{array}$ \\
\hline 2010 & $\begin{array}{l}\text { The Effect of Mother Tongue on Foreign Language Learning and Success as a Mo- } \\
\text { tivation Factor }\end{array}$ \\
\hline 2010 & $\begin{array}{l}\text { The Effect of Foreign Language Education and Mother Tongue Education Starting } \\
\text { at the Same Time on the Basic Language Skills of Primary School First Grade Stu- } \\
\text { dents }\end{array}$ \\
\hline 2010 & $\begin{array}{l}\text { The Effect of Formative Assessment on Learners' Test Anxiety and Assessment } \\
\text { Preferences in EFL Context }\end{array}$ \\
\hline 2010 & Speech Act in Foreign Language Teaching \\
\hline 2011 & $\begin{array}{l}\text { Level of Realization of Affective objectives of Primary School First Grade Foreign } \\
\text { Language Teaching Programs about Foreign Language Education to Students }\end{array}$ \\
\hline 2011 & $\begin{array}{l}\text { Evaluation of Design and Application Process of Computer Programs Used in For- } \\
\text { eign Language Teaching }\end{array}$ \\
\hline 2011 & $\begin{array}{l}\text { Learning Objects in Web-Based Foreign Language Teaching (Effect on Achieve- } \\
\text { ment, Persistence and Attitudes) }\end{array}$ \\
\hline 2011 & $\begin{array}{l}\text { An Investigation into the Implementation of Alternative Assessment in the Young } \\
\text { Learner Classroom }\end{array}$ \\
\hline
\end{tabular}


Reflection of the Accession Process of Turkey to European Union on Doctoral Theses Written About Foreign Language Education in Turkey 1987-2017

Table 2: Titles of PhD Theses on Foreign Language Education by Years.

\begin{tabular}{|c|c|}
\hline Year & Title \\
\hline 2012 & $\begin{array}{l}\text { The place of Idioms in Turkish and German in Daily Communication and their } \\
\text { Reflections on Foreign Language Teaching }\end{array}$ \\
\hline 2012 & $\begin{array}{l}\text { Relationship Between Anxiety, Shyness, Strategy and Academic Success in Second } \\
\text { Language Learning }\end{array}$ \\
\hline 2012 & $\begin{array}{l}\text { The Effect of of Mobile Multimedia Support for Printed Materials on Vocabulary } \\
\text { Learning and Motivation in Second Language Teaching }\end{array}$ \\
\hline 2013 & Function of Translation in Second Language Teaching \\
\hline 2013 & $\begin{array}{l}\text { The Place of Written Expression in New Approaches to Foreign Language Teach- } \\
\text { ing in French: Implementation of Common European Framework of Reference for } \\
\text { Language Education and Action-Oriented Approach for Languages }\end{array}$ \\
\hline 2013 & $\begin{array}{l}\text { Intercultural Reading and Developing Reading Skills in Intercultural Interactive } \\
\text { Second Language Teaching }\end{array}$ \\
\hline 2013 & $\begin{array}{l}\text { The Effect of Differentiated Second Language Teaching on Achievement, Critical } \\
\text { Thinking and Creativity in Gifted Students }\end{array}$ \\
\hline 2013 & $\begin{array}{l}\text { Improving Preservice English Language Teachers' ICT Skills and Developing Pos- } \\
\text { itive Attitudes towards the Use of Technology in Language Teaching Through an } \\
\text { Online Course }\end{array}$ \\
\hline 2014 & $\begin{array}{l}\text { Silence in Foreign Language Learning: Analysis of Risk Taking Behaviors of Stu- } \\
\text { dents of English Class as a Foreign language education: A Case Study of Atatürk } \\
\text { University English Language Teaching Program }\end{array}$ \\
\hline 2014 & $\begin{array}{l}\text { Anxiety on Learning Turkish as a Second Language and The Effect of Anxiety on } \\
\text { Foreign Language Achievement }\end{array}$ \\
\hline 2015 & $\begin{array}{l}\text { An Investigation into the Applicability of Chomsky's Cognitive Language Ap- } \\
\text { proach to Foreign Language Education }\end{array}$ \\
\hline 2015 & The Effect of Model-Based Lesson on Writing Skills in Foreign Language Teaching \\
\hline 2015 & $\begin{array}{l}\text { The Effects of Vocabulary Building with Emotion- Based Memory Strategies and } \\
\text { Practices on Performance and Acquiring Levels of Students in Foreign Language } \\
\text { Teaching }\end{array}$ \\
\hline 2016 & $\begin{array}{l}\text { Investigation about the Effects of Ubd (Understanding Based Design) Practices } \\
\text { Based on Action Research in Foreign Language Teaching on Teachers and Stu- } \\
\text { dents }\end{array}$ \\
\hline 2016 & $\begin{array}{l}\text { Investigating Factors Related to the Use of Self-Regulated L2 Learning Strategies } \\
\text { in a Second Language Education Context }\end{array}$ \\
\hline 2016 & $\begin{array}{l}\text { Investigation of the Effect of Authentic Task Oriented Applications on Foreign } \\
\text { Language Education }\end{array}$ \\
\hline 2017 & $\begin{array}{l}\text { Intercultural Communication in Foreign Language Teaching: Examinations of } \\
\text { Teachers' Views in Turkey and France Case Studies }\end{array}$ \\
\hline 2017 & $\begin{array}{l}\text { Teaching and Learning of Vocabulary in Primary Schools for Teaching French as } \\
\text { a Second Language according to EU Common Application Text }\end{array}$ \\
\hline
\end{tabular}

According to Table 2, when the titles of the doctoral theses prepared in the foreign language education are examined, foreign language education and foreign language learning are the concepts clearly presented in all of the titles of the dissertations prepared between 1987 and 2003. However, these concepts are not seen in all of the titles of 
the doctoral theses prepared between 2004-2017. On the other hand, teaching methods and techniques, current approaches in foreign language education and new trends, what students benefit from foreign language learning, foreign language education in early age, second language education for individuals in need of special education, culture in second language education, factors affecting learning, foreign language learning, anxiety, personality, learning styles and shyness concepts are used in the titles of doctoral theses. It is observed that in doctoral theses, studies on the transition process to European Union in foreign language education started to be conducted in 2005. The issues that are examined in doctoral theses have changed with the effect of Turkey-EU membership negotiations. These issues are;

- Creative writing skills

- Creative thinking skills

- Understanding By Design

- Mobile Multimedia Support

- Web based Foreign Language Teaching

- Detailing Theory

- Intercultural Communication

\section{Discussion and Conclusion}

Member countries of European Union have common educational objectives. In the membership process to EU, Turkey took decisive steps and made regulations in all areas, such as science, research, financial control, food security, energy, foreign policies, agriculture, laws of companies. Education is a primary issue for EU countries and Turkey for being a society of knowledge is the key of prosperity and civilization. Turkey has made significant improvements in all the organizations to meet the requirements of EU education chapter and made rearrangement in the lesson programmes. The pivotal points of EU education policies are critical thinking, creativity, competence in digital education, use of technology, communication skills, entrepreneurship, constructivism, student-centered education and multiple intelligences theory and foreign language education. As stated in this study, ministry of Turkish national education and 
higher education took these concepts into consideration and scheduled new courses in the new Turkish educational program. In particular, foreign language teaching in Turkey as in EU member countries is a significant issue which the educators, academics, and the ministry of National Education work on. Turkey changed curriculum and rearranged weekly language course hours. Lifelong Education programmes have been implemented by Higher Education and Ministry of National Education, which give teachers and student opportunities to learn European culture and practice English and other European languages.

Postgraduate studies on foreign language education in Turkey have gained more importance for these studies bring solutions for the problems in foreign language education in Turkey and provide useful insight for effective foreign language education. When the reflections of Turkey's accession process to EU membership on doctoral theses related to foreign language education are analysed, the published doctoral theses on foreign language teaching in Turkey after 2004 center upon the learner, the use of technology, current approaches, alternative methods and techniques for better and more effective second language learning and teaching, and communication. European Union gives importance to the use of communication in learning a foreign language, intercultural communication and foreign language education for preschool children. In the study, it is found out that there are doctoral studies on intercultural communication and language education at early ages.

Pre-school education is a crucial period in terms of language acquisition. In this period, children should receive foreign language education for they can learn more quickly, easily and permanently. It can be seen that the child"s being in an environment full of language rich stimuli, the interaction of peers and playing various games help him/her easily acquire language. This study shows that there is one doctoral thesis on foreign language learning in preschool education in Turkey, which was published in 2008 'Foreign Language Learning at early ages: A Study on Factors Affecting Foreign Language Learning of Preschool Children.' It is obvious that there have not been any academic research on the proficiency and motivation of language teachers in pre-school education. 
Successful foreign language teaching lies in using creative and critical thinking skills effectively. In foreign language classes, students tend to avoid asking questions. Learners' being critical thinkers help them activate their communicative competence and performance. As mentioned in the article, one of the main points in foreign language education European Union attaches importance is critical thinking in foreign language education. In this study, it was found out that the when doctoral theses published in Turkey are examined, there is one doctoral thesis on critical thinking in foreign language education, which was published in 2013: 'The Effect of Differentiated Foreign Language Teaching on the Effect of Learning Level, Critical Thinking and Creativity of Gifted Students.' There is a need to explore foreign language acquisition with critical thinking technique at the primary education level. Doctoral theses on foreign language education in Turkey are focused only on undergraduate students, gifted students and high school students.

In conclusion, this study specifically explored how Turkey's EU full membership process affected doctoral studies on foreign language education and what research topics in doctoral theses related to foreign language education academics worked on between 1987 and 2017. It is clear that the number of doctoral theses on language teaching increased significantly between 2004 and 2017. This situation can be associated with the increase in importance to higher education and doctoral studies with the start of the EU process. This study shows that In Turkey's transition process to EU membership, the research topics in doctoral theses on foreign language teaching mostly focused on are creative writing skills, creative thinking skills, Understanding by design, Mobile Multimedia Support, Web-based Foreign language teaching, Detailing Theory, Intercultural Communication.

The following topics can also be suggested for further academic studies:

- The effects of Lifelong Learning Programmes on the language acqusition of Turkish studens and teachers.

- The effects of Bologna process on English proficiency levels of University students in Turkey 
- Comparison between foreign language education of EU member developing countries and Turkey in terms of actors ( students and teachers)

- Transformative language learning In Europe and its applicability in Turkey

- Digital language education in Europe and Turkey.

\section{Kaynakça / References}

Bailly, S ., Devit, S., Gremmo, MJ. , Heyworth, F., Hopkins, A., Jones, B., Makosch, M.and Riley, P. and Stoks, G. and Trim, J. (Ed.) (2001). Common european framework of reference for languages: learning, teaching, assessment, Council of Europe, Language Policy Division, Strasbourg.

Cansever, BA. (2009). Educational policies of european union and evaluation of turkey's adaptation process to these policie., International Online Journal of Educational Sciences, 1 (1), 222-232.

Çakmak, ÖA. (2006). Avrupa Birliği'nin beşinci genişleme süreci: Yeni üye ülkeler ve türkiye'nin rekabet durumları. Gazi Üniversitesi iktisadi ve İdari Bilimler Fakültesi Dergisi 8(1), 79-94.

Çelik,Z. (2012). The transformations experimented within the Turkish Education System in the context of policy and implementation: the case 2004 curriculum reform, Doctoral Thesis, Institute of Social Sciences, Hacettepe University, Ankara.

Chapter-26-Education and Culture, (2020). Financial and Social Policies. Department of Economic, Directorate for EU Affairs, Ministry of Foreign Affairs, Republic of Turkey, retrieved April 10, 2020, from https://www.ab.gov.tr/chapter-26-education-and-culture 91 en.html Council of Higher Education, Thesis Center, https://tez.yok.gov.tr/UlusalTezMerkezi/

Demir, Ç. (2020). Holistic analysis of postgraduate theses on foreign language teaching in turkey with actor-technic perspective 1987-2017. published PhD thesis, Istanbul Aydin University, Istanbul.

EU in Brief, (2019). Goals and values of the EU. European Union Official Website, retrieved May 10, 2020, from https://europa.eu/european-union/about-eu/eu-in-brief en.

European Commission/EACEA/Eurydice, (2015). The European Higher Education Area in 2015: Bologna Process Implementation Report. Luxembourg: 
Publications Office of the European Union, retrieved May 3, 2020,from https://uluslararasi.yok.gov.tr/Documents/Uluslararasilasma/uygulama raporu 2015.pdf

Gazzola, M. (2016). Research for cult committee european strategy for multilingualism:benefits and costs research group in languages and economics ("REAL" Group). Department of Eucation Studies of Humboldt-Universität zu Berlin, and Institute for Ethnic Studies, Ljubljana, Slovenia.

Kulaksız, E. (2010). Participants opinions on the implementation of the EU comenius Turkey. Doctoral Thesis, University of Social Sciences, University of Kocaeli.

Kıral, B. (2020). Nitel bir veri analizi yöntemi olarak doküman analizi. Sosyal Bilimler Enstitüsü Dergisi, 8(15), 170-189.

Language Policy Division, (2007). From linguistic diversity to plurilingual education. guide fort he development of language education policies in Euro. Strasbourg: Council of Europe, retrieved February 3, 2021 from, https://rm.coe.int/16802fc1c4.

Mazza, C., Quattrone P., Riccaboni, A.(2008). European Universities in Transition: Issues, Models and Case., UK: Edward Elgar Publishing.

MEB, (2017). Müfredatta yenileme ve değişiklik ( Press announcement).Talim Terbiye Kurulu Başkanlığı, Ankara, retrieved January 10, 2021, from http://ttkb.meb.gov.tr/meb_iys_dosyalar/2017_07/18160003_basin_aciklamasi-program.pdf

Sağlam, M., Özüdoğru, F., Çıray, F. (2011). The European union education policies and their effects upon Turkish education system. Yüzüncü Yıl Üniversitesi Ĕ̆itim Fakültesi Dergisi. 8(1), 87-109.

Sayın, Y. (2016). Türkiye'nin Avrupa Birliği'ne katılım müzakereleri ve müzakere fasılları. Selçuk Üniversitesi Sosyal Bilimler Meslek Yüksekokulu Dergisi, 19 (2), 41-62.

Schuller BJ., Lidbom, M. (2009). Competitiveness of nations in the global economy. Is Europe internationally competitive?. Economics and Management, Lithuania, Kaunas University of Technology. ISSN 1822-6515.

Özer, MA.(2009). Avrupa Birliği'ne tam üyeliğin eşiğinde Türkiye. Yönetim ve Ekonomi,16 (1), 89-105, Celal Bayar Üniversitesi, İ.̇̇.B.F., Manisa.

Turkish Industrialists' and Businessmen's Association, (2008). Higher Education in Turkey: Trends, Challenges, Opportunities. TUSIAD Publication, Istanbul, retrieveMay2,2020,from https://www.iepqaa.org/downloads/publications/Turkey_trends_challenges_opportunities.pdf 


\section{Kaynakça Bilgisi / Citation Information}

Demir, Ç. (2021). Reflection of the process of Turkey to European Union on doctoral theses written about foreing language education in Turkey 1987-2017. OPUS-International Journal of Society Researches, 18(39), 10-28. DOI: 10.26466/opus.826337 